\title{
Online lockdown diaries as endurance art
}

\author{
Guobin Yang $^{1}$
}

Received: 5 October 2020 / Accepted: 11 December 2020

(c) The Author(s), under exclusive licence to Springer-Verlag London Ltd. part of Springer Nature 2021

\begin{abstract}
When the city of Wuhan was severely locked down on January 23, 2020 for 76 days due to the coronavirus outbreak, many residents started writing "lockdown diaries." This article argues these diaries constitute a kind of performance art for their authors, specifically, an 'art of endurance' as described by Shalson (2018). Keeping a diary requires a plan, but the following through of the plan is a contingent process requiring efforts and endurance. The challenges become particularly daunting for authors of online diaries in pandemic times. The article analyzes multiple types of endurance associated with the Wuhan lockdown diarists, showing that in digitally-driven environments, where potential collective responses are a key context, the lockdown diaries of Wuhan, like works of endurance art, engage with meanings that reach far beyond their original experience and context. Their stories of endurance are an allegory of the endurance of the entire city of Wuhan.
\end{abstract}

Keywords Pandemic $\cdot$ Online diary $\cdot$ Social media $\cdot$ Endurance art $\cdot$ COVID-19 $\cdot$ Fang fang $\cdot$ Wuhan $\cdot$ China $\cdot$ Digital era $\cdot$ Personal testimony $\cdot$ Iteration $\cdot$ Documenting performance $\cdot$ Performing documents

\section{Online lockdown diaries as endurance art}

After the city of Wuhan was shut down on January 23, 2020 due to the coronavirus outbreak, many residents in Wuhan started writing “lockdown diaries" (封城日记), which they shared on social media. Initially, there were only a few, but then some became viral. Within weeks, there was an explosion of diary-writing and posting online. Some of the diarists stopped writing when the lockdown was lifted on April 8; others continued. By August, 2020, I had collected several thousand diary entries produced by hundreds of writers. Some of these were written by residents in other cities; most were produced by Wuhan residents, ranging from teachers, medical workers, COVID-19 patients, government officials, and IT professionals to students, poets, novelists, and community volunteers.

Most of these diaries were written in a traditional diary form. Entries typically started with information about dates, weather, and in some cases, and the latest tally of COVID19 cases. They were one to two pages long, although some entries ran much longer, often because they contained many photographs. The most popular online platforms for

Guobin Yang

guobin.yang@asc.upenn.edu

1 University of Pennsylvania, Philadelphia, USA posting lockdown diaries were WeChat and Sina Weibo: some authors posted their diaries simultaneously on both platforms. Video diarists (or vloggers) typically shot short videos on cell phones and then uploaded the videos to video platforms, such as YY, Red, and Douyin (the Chinese version of TikTok).

These forms of lockdown diaries documented both personal and collective struggles. The abrupt shutdown of a city of 11 million people stunned China and the world, and lockdown diaries brought home the visceral reality of the closed city, and the pandemic. As soon as they appeared, these diaries began to attract scholarly attention (Yang 2020; Bao 2020). Bao (2020) has studied three women's diaries in Wuhan, China, with a focus on their engagement in feminist issues. A team of Polish scholars have used pandemic diaries to study life in isolation in Polish society (Eukianow et al. 2020). Anthropologists have been studying the disruptions to life and work caused by the pandemic as well as how people use pandemic diaries to make sense of the disruptions (Manley 2020). Diaries have long been studied as a form of personal writing and life narrative (Ben-Amos and Ben-Amos 2020; Lejeune 2009a, b; Martínez García 2020; Plummer 2001; Rak 2020). The COVID-19 pandemic presents a set of new circumstances for the production, reception, and study of diaries. The appearance of large numbers of pandemic diaries in different parts of the world is unprecedented. From 
Valencia, Spain and St. Petersburg, Russia to Pittsburgh in the U.S., pandemic (or quarantine) diaries were written and shared online (Nierenberg 2020, March 30). The most remarkable feature of this phenomenon, which distinguishes it from the conventional diary, is the online publishing and sharing (Lejeune 2009a). Posting diaries on social media gives them audiences unavailable to the traditional diary. The audiences themselves are networked (boyd 2010; Marwick and boyd 2011). Interactions and engagement with the networked audiences are a writing incentive to diary writers, but as we will see in the case of Wuhan lockdown diaries, they may also bring unwanted attention and scrutiny.

In the U.S., according to one account (Rettberg 2020), the earliest online diaries appeared around 1994. In China, the personal home pages (Yang 2009) which blossomed in the late 1990s often published diary-like writings of their editors. The first well-known online diary appeared in 2000, when the popular online literature website Under the Banyan Tree serialized the online diary of Lu Youqing (陆幼青), who was dying of cancer. Lu's diary chronicled his struggle with cancer and won a large following (Hochx 2015). Online diary-writing became widely known with the introduction of blogs to China in 2002. The Chinese translation for blog, 博客, is credited to one of China's internet pioneers Fang Xingdong. But the concept of the blog and the practice of blogging owe much of their initial popularity to one blogger's online diary-Muzimei. A young woman based in Guangzhou, Muzimei began to serialize her diary about her sexual exploits on her blog hosted by blogchina.com on June 19, 2003. These blog entries were explicit in sexual content, a daring challenge to mainstream mores of sexuality, marriage, and freedom of expression. Muzimei's online diaries not only brought fame (or infamy for her critics) to her own blog and the website blogchina.com, but they also boosted web traffic in many other web sites where the controversies about her diaries raged (Farrer 2007).

If Muzimei's online diaries were popular in 2003, the size of their popularity was limited by the size of the internet population. But the internet developed rapidly in China (Guo 2020; Han 2018; Hu 2008; Negro 2017; Qiu 2009; Yang 2009). China had only about 80 million internet users in 2003, compared with 940 million as of June 2020 (CNNIC, 2020). The most popular social media platforms today, Sina Weibo and the "super-sticky" WeChat (Chen et al. 2018), appeared only after 2009. And Weibo and WeChat were the main platforms for posting lockdown diaries.

Even in ordinary times, keeping a diary takes efforts; it requires self-discipline and perseverance. A pandemic-induced lockdown exacerbated the hardship. Wuhan diarists had to overcome obstacles of time management, boredom, mental and physical exhaustion, and censorship. Writing and posting diaries during the lockdown was an ordeal and an accomplishment. In addition to enduring the lockdown like others around them, diarists were also enduring the consequences of their commitment to iterative online publishing: keeping up with repeated posting on social media and managing responses. Each iteration carried forward and partially re-enacted the entries that came before it, so that the whole series of diary entries became an ongoing dialogue with both the self and the diarist's networked audiences. The fact of iteration itself became its own motivator. Writing lockdown diaries became a practice of endurance art.

In 'Performing Endurance: Art and Politics since 1960', Lara Shalson (2018) examines the intentional performance of endurance in both art and life. Conventional wisdom associates endurance with pain, ordeal, and hardship: Shalson directs attention to endurance as a form. Using Chris Burden's 1971 "Shoot" as an example, she suggests that all endurance art has a simple structure: "it involves a plan and a following through of that plan... (except that) the plan, like all plans, can never guarantee its outcome in advance" (Shalson 2018, p 9). She continues:

Endurance is built on a plan, then, but this plan does not fully dictate what the work becomes. The artist designs and then endures an unfolding of events that can never be fixed from the start. This indeterminacy arises from another essential element of endurance: namely, that it is always performed in relation to forces that are beyond the performer's control. (Shalson 2018, p12).

The indeterminacy here is key to the parallels with the uncertain promise of digitally-mediated social connectivity. Posting publicly, repeatedly, has no guarantee of result, and is therefore its own end-an offer, or performance, with no guaranteed outcome. This is arguably also a status or condition of traditional handwritten diaries: the French diary scholar Philippe Lejeune defined a diary as "a series of dated traces."(Lejeune 2009b, p 179): a "series," because it is kept over a period of time, the accumulation of entries over time transforming the status of individual entries into more than constituent parts. The effort to sustain the act of iteration turns diary-writing into an act of endurance. At the same time, the digital sphere gave individuals under lockdown a unique opportunity to lay down a record of what was happening to them as it happened.

The acts of writing and posting a diary were acts of personal agency in an otherwise contingent, uncontrollable reality, one that depended on the ability to make this repeated gesture in a consciously collective context - in this case, social media.

\section{Wuhan: a unique lockdown experience}

I started collecting lockdown and pandemic diaries as soon as Wuhan was shut down. I followed some of the diarists on Weibo and WeChat, and searched for diaries using the 
Chinese search engine Sogou. Reader comments on diary posts were also selectively saved. The diaries cited in this article come from this personal research archive. For diarists cited in this article, I use real names if they are already well-known public figures (e.g. Fang Fang 2020; Guo 2020) or if I have permission from their authors. Otherwise, I use pseudonyms to protect their anonymity. Chinese names mentioned here follow the Chinese convention of family name first, given name second. All diary quotations are translated into English by myself. Many of the diaries have since disappeared from the web, making it unhelpful to provide their original URLs. Instead, I have used the following citation format: Diary name (or pseudonym), followed by the date of the entry, as in: Guo Jing Diary, February 7, 2020.

Although citizens in many countries have had lockdown experiences during the COVID-19 pandemic, the lockdown experience in Wuhan had its unique features. No other city in China or the world was sealed off as abruptly, decisively, and tightly as Wuhan. Beginning on January 23, 2020, all outbound and inbound traffic - air, railway, highway, waterways, was simultaneously suspended; traffic within the city was similarly highly controlled. From February 16 to April 8,2020 , all residents were forbidden from leaving their residential communities. Although community workers and volunteers helped to deliver medical and daily necessities during this period (Mei 2020, p. 319), grocery shopping was especially challenging and residents often had to organize their own ways of purchasing grocery. Many lockdown diarists, almost all women, documented in detail how they managed shopping for grocery when they could no longer leave home. The typical method was group shopping, because grocery stores stopped taking individual orders online and did not allow in-person shopping. WeChat groups, which had always been a popular feature of the instant messaging platform, became a convenient way of organizing grocery shopping. Li Meng and Qin Yin wrote that they and their friends in Wuhan all set up and joined multiple WeChat groups for grocery shopping; one person joined about 20 such groups (Li Meng's Diary, February 17, 2020; Qin Yin's Diary, February 17,2020$)$. Ning, a psychology counselor, wrote frequently about her WeChat group shopping experiences. On February 25, 2020, she reported her new daily routine: the first thing she would do when she woke up in the morning was to check the WeChat grocery shopping groups for shopping information. Because there were so many groups, she would have to go through long threads to find the information she needed (Ning's Diary, February 25, 2020).

Diarists were aware of the unprecedented nature of the Wuhan lockdown. As witnesses, they wanted to document personal history in an extraordinary historical event, and leave a personal record. Mr. Amber, a Wuhan native and prolific diarist, was staying with his parents in Wuhan during the lockdown. In his last entry, written on the last day of the lockdown, he summed up his total output: 76 diary entries for 76 days of the lockdown, totaling 143,000 words, in addition to 40 poems and some occasional essays. A selfconscious diarist, he explained to himself repeatedly why he was keeping a diary and reminded himself again and again to persevere to the end of the lockdown. On January 28, the sixth day of the lockdown, he wrote that his original intention in keeping a diary was to document his and his family's life:

My diaries are a running account, but the records are true. Therefore, in my heart I feel that my "Lockdown Diary" is meaningful. Maybe meaningful only to myself. One day when I look back in my old age, it will be the "Grand Historical Record" (史记) of part of my life. ${ }^{1}$ It is said that there are two most valuable words in the world. One is "self-discipline." The other is "persevere." Self-disciplined people keep changing themselves. People who persevere change fate. I must persevere. I will persevere [in my diary writing] till the end of the anti-coronavirus and stay-home life! (Mr. Amber's Diary, March 28, 2020).

A Ms. L wrote:

To do one thing well requires a strong will. It requires a clear goal as guidance. Giving up is easy. When there are hardships, obstacles, and one difficulty after another, one must overcome laziness and cheer oneself on, in order to persevere. Only in this way can one act more effectively. Neither the continuation of the pandemic nor the busy work schedule after the resumption of class has caused me to skip even a single day of diary. I have written close to 100,000 words. The daily habit of writing makes me overcome all difficulties. Nothing can stop me from writing, rain or wind. (Ms L's Diary, May 22, 2020).

A sense of community developed through the sharing of pandemic diaries and the encouragement from readers. Lena Buford's (2020) study online diaries in the early years of the internet history in the U.S. finds that people who posted online diaries built personal connections in online spaces, leading to the appearance of online diary communities. Diarists derive satisfaction from being recognized by readers or viewers. Readers cheer diary-writers on by sharing supportive comments. Mr. Zhang, for example, often reported how happy he was to see that a particular day's entry had reached hundreds of views, or how flattered he was to receive compliments from his friends or former teachers.

The contents of the lockdown diaries reflect the changing circumstances of the efforts to control COVID-19 and the

\footnotetext{
${ }^{1}$ Records of the Grand Historian, written by Sima Qian (c. 145 - c.
} $86 \mathrm{BC}$ ), is often considered the greatest historical work in China. 
impact of these measures on personal lives. In the first week of the lockdown, initial reactions include panic shopping and feelings of personal helplessness. For example, a diary entry dated January 272020 by feminist activist Guo Jing says:

Today, the weather was a bit clearer, but still cloudy. After walking for only a few steps outside, I saw two cats on a pile of debris. We stared at each other. The scene had such a strong sense of the apocalypse. When we stared at each other, it seemed as if there were only me and the two cats left in this world. (Guo Jing's Diary, January 27, 2020).

February in Wuhan saw the peak number of daily confirmed cases of coronavirus and daily deaths. Diarists writing on February 7 usually mentioned the death of Dr. Li Wenliang on that day. Li Wenliang had been widely reported as an early whistleblower who then contracted the disease on the job. February was also the month when the efforts to contain COVID-19 were at their most austere, and many diaries record a rigid regimen of community isolation and quarantine. A graduate student who volunteered to work as a guard at the entrance of a residential community reported that she started work at around noon.

At 12:30 p.m., two lunch boxes were delivered to the volunteers at the gate. At 1:08 p.m., a man in his $30 \mathrm{~s}$ passed by and asked for a pair of gloves. The man told her he was going to visit his wife in the hospital, and he had to wear gloves to be let in. She gave him the gloves. At 2:35 p.m., a white-haired elderly woman in her $80 \mathrm{~s}$ appeared and said she was going out to buy some lunch. Instead of letting the elderly lady out, she gave her a free lunch meal and persuaded her to return to her apartment. (Ms Hu's Diary, February 20, 2020).

A most extraordinary aspect of the fight against COVID19 in Wuhan was the rapid construction of specialized and fangcang temporary shelter hospitals. Health care workers and COVID-19 patients provided rich personal documentation of life in these facilities in diaries, social media postings, and video blogs. One of the viral video blogs showed medical workers and patients cheerfully performing public square dances inside one of the temporary hospitals. Square dancing was ubiquitous in China's pre-COVID-19 urban landscape. For some, seeing it again boosted morale, while others saw it as inappropriate for a time of national suffering.

Ah Nian (阿念) is the web name of Wu Shangzhe (吴尚 哲). A 26-year-old Wuhan native who works in Beijing, she traveled back home to Wuhan on January 19, 2020 for the Lunar New Year holiday. She was diagnosed with COVID19 on February 13, 2020 and moved to a temporary shelter hospital the same day. The next day, An Nian started posting diaries on Sina Weibo and vlogs on Douyin. Her Weibo postings were mostly short, some as brief as one phrase or one sentence, but their brevity conveyed a special urgency and force. Thus her first posting on Weibo starts with:

Shelter Hospital Diary Day 1: \#Valentine'sDay\#. My residential community sent a police car to take me to the shelter hospital... I will try to be the most optimistic girl in the hospital. (Ah Nian Weibo Diary, February 14, 2020).

Her second posting on Weibo, put up on the same day, goes:

Shelter Hospital diary: The patient in \#72 bed suddenly burst into loud howling with her hands reaching forward. She was not speaking clearly and was trembling. My heart sank. I hurried to the help desk to get a nurse. I thought she must be suffering badly from the disease, but it turned out it was because of her personal relationships. (Ah Nian Weibo Diary, February 14, 2020).

By March, COVID-19 had been contained in China, but was getting worse in other countries. In the U.S., incidents of racism against ethnic Chinese and Asian Americans increased significantly (Cheung et al. 2020). Far-right conservative protests to defend their liberty of not wearing face masks were widely reported (Wilson 2020, April 17). These stories were translated into Chinese and circulated on Chinese social media, causing great fear and trepidation. Many diarists took note of these changes. Mr. Zhang, for example, who started posting diary entries on January 27, by March 18 had posted 49 entries, and wrote he would now turn his attention to the outside world. His son was studying in the United Kingdom and incidents of racism against Chinese students there worried him. For several days he posted diaries in the form of letters to his son, offering advice about how to manage his stay-at-home life in a foreign country. These diaries attracted other parents with children studying abroad. Ms. Ma noted in her diary on March 1, 2020 that 58 countries in the world had now reported cases of COVID-19. She commented that in northern Italy, although multiple towns were locked down, residents in one town rallied in a plaza to demand freedom. After enumerating a long list of such COVID-19-related activities in foreign countries, she summed up her thoughts with these words from Yuval Harari: "Never underestimate human stupidity" (Ms Ma’s Diary, March 1, 2020). Sentiments of nationalism were arising. 


\section{Types of endurance}

Initially, diarists had no idea how long the lockdown would last, and few expected it would last as long as it did (76 days). The unknowable nature of the end point caused anxiety. Diarists were highly conscious of the number of days the city had been under lockdown, and counted the number of entries they had written by numbering them. Writing down numbers and dates were an important part of the activity. "Lockdown Diary 12, 12th day of lockdown, February 3, 2020," Tao Tao wrote at the top of her entry for that day (Tao Tao Diary, February 3, 2020). "Lockdown Diary (60), March 22, 2020, Sunday," wrote Chu Ma and Xuan Yue (Diary of Two Walking Trees, March 22, 2020). February 21, the thirtieth day of the lockdown, was taken as a milestone by many. Fang Fang started her diary for that day by saying: "The thirtieth day of the lockdown. My Heavens. It's been so long." (Fang Fang Diary, February 21, 2020). Tao Tao wrote, "It's been 30 long days. If I hadn't been writing a diary, I would not know how many days it has been. Thinking back to a month ago feels like another world." (Tao Tao Diary, February 21, 2020). To live with this intense awareness of the passage of time, reflected in the counting of every passing day, while completely incapable of knowing when such days would come to an end, was to endure. In this sense, endurance was to constantly remind oneself one was living with an unknown future.

Another kind of endurance was self-doubt. Some authors felt that life was disrupted by the pandemic on such a scale that keeping a daily account of one's personal life might seem trivial. Others experienced an acute sense of powerlessness induced by a quarantined life, and fought to resist self-pity. Guo Jing was initially hesitant when a friend encouraged her to start a diary. She did not wish to be seen as a victim and did not feel she was among the most unfortunate, saying "it took courage to recognize one's powerlessness." She pondered the meaning of keeping a diary from the perspective of a feminist activist:

As an advocate of gender equality, I know better than others that to solve a social problem, it is first necessary to tell it. I decided to try to keep a diary, because I do need support now. (Guo Jing Diary, January 25, 2020).

Telling her personal story and sharing her diaries with others became a way of managing her self-doubt and powerlessness.

A further type of endurance was practical: mental and physical exhaustion. Writing up a one-page diary in Chinese characters can be remarkably time-consuming. Publishing one's diary on social media requires additional attention and labor. Some diarists commented on the hardship of this work. After finishing writing her diary on January 27, 2020, Guo Jing was so exhausted she had to lie in bed for a couple of hours: "It never occurred to me before that writing a diary was so mentally and physically exhausting. The lockdown freezes time and space, but at the same time magnifies our emotions and feelings. I've never paid so much attention to myself." (Guo Jing Diary, January 25, 2020) For Mr Zhang, writing had long been a habit and an essential part of life, "as important as breathing and sleep," (Mr. Zhang's Diary, February 14, 2020), but during the pandemic he felt that he could now not write every day. Under lockdown, he found he lacked time, energy and focus to properly revise, proof-read, insert photo images, and prepare posts for sharing every day. It was a vicious circle: at one point he lost sleep because he had spent so much time trying to write his diary that he had not had enough time to do physical exercise. And lacking sleep, he could not always keep up with his daily writing.... (Mr. Zhang's Diary, February 1, 2020).

This practical endurance was a feature of diarists who were frontline health care workers, COVID-19 patients, or volunteers who only had time to write after a day's work. Dr. Zha, a physician sent from Shanghai to Wuhan, wrote 67 diary entries during her 68 days in Wuhan. In her entry on February 18, she wrote that she was too exhausted to write anything that day:

It is so hard to balance between all kinds of good wishes and reality. Today was the most exhausting day for me since I came to Wuhan. I don't want to do a thing. Don't even have the strength to talk. (Dr. Zha's Diary, February 18, 2020).

Diarists had to endure both attention and its absence. To post entries on social media is an invitation for reader engagement: some diaries had few readers while others went viral. Neglect and/or fame was a constant source of anxiety. While diarists wanted their works to be read, they could not control readers' reaction. Tao Tao, a mother of a 12-year-old son, wrote:

There are many things I want to write about-dreams, love, and even my trivial everyday life. Some things I wrote, I later cut. I want to be known, but fear to be known. I want to be understood, but do not want to be controlled. There are some secrets in the notes I make and musings to myself that will stay in my draft folder. I'm open-hearted and frank, but that brings the fear of being misunderstood. (Tao Tao Diary, April 1, 2020).

Finally, diarists had to endure the risks and realities of the ephemeral nature of cyberspace. Web sites and the information on them are constantly refreshed and updated, which would mean information constantly degenerates and is erased. There is something fundamentally ephemeral about 
the web (Chun 2008). Many websites and web postings disappear quickly, not the least because of censorship in China (Yang and Wu 2017). On February 1, the poet Xiao Yin wrote that he had archived ten postings for future use on his WeChat, but when he opened them again in the evening, five of the ten were gone, a "death rate" of 50 percent (Xiao Yin Diary, February 1, 2020). On February 28, he noted that he had written 38 diary entries about the Wuhan epidemic. Yet only about a dozen of them survived censorship; others were all censored for unknown reasons. Even so, he continued to post his diary entries. On March 2, 2020, Xiao Yin told his readers that it took him an hour and a half to publish his diary for that day. It simply would not go through after repeated attempts to post it. He checked his use of words meticulously. In the end, it went through after he changed one word in the following passage:

Even when the epidemic situation is so grave, we still see that some people are lax and lazy in doing their job. There are always people who depend on the operations of the monster machine and benefit from the dividend of the rules. The same danger has another manifestation. To make sure that they don't get into trouble, some people would rather move further to the left [of the ideological spectrum]. You never get into trouble for singing praise. (Xiao Yin Diary, March 2, 2020).

The next day, Xiao Yin revealed the one-word secret. The original text that prevented his diary from being published was the word "left" in "further to the left" (左一点). It worked after he changed "left" to "radical" (激进). Even Xiao Yin did not understand exactly why "left" was a more sensitive word than "radical."

\section{Endurance and/as digital virality: the Case of Fang Fang}

The other side of the coin of ephemerality was the unforeseen consequence of virality. As the pandemic evolved beyond Wuhan, words written in one set of circumstances took on new meanings. Fang Fang's diary became the best known of all lockdown diaries, perhaps unsurprisingly because she was a famous Wuhan novelist. From late January to late March she posted 60 diary entries on social media, mostly her observations and reflections about the pandemic and the havoc it was wreaking on her native city. She felt the pain of her fellow Wuhan residents, and called on the public to hold government officials accountable for their actions or inaction. She mourned the dead in moving language, and her sharpness, empathy, and insights endeared her to millions of readers in China and beyond. Each of Fang Fang's diary entry became a social media sensation, with her readers waiting up late to read the new post, sometimes as late as 2:00 or 3:00 a.m. Reporting on April 10, 2020, about two weeks after Fang Fang had stopped writing her lockdown diary, a story in the The Guardian states that "On Weibo, 'Fang Fang Diary' has had 380 m views, 94,000 discussions, and 8,210 original posts, peaking last week" (Davidson 2020, April 10).

The viral success of Fang Fang's diary brought on scrutiny and personal attacks. Initially, her detractors blasted her diaries for being too critical and "negative," complaining that they lacked "positive energy." Then, in late March when news came that an English version of Fang Fang's diary would be published in the United States, she began to be called a traitor. By making her diaries available to US readers, the accusation went, she had "handed over ammunition" to US politicians who were already blaming their own pandemic failures on China. Fang Fang had criticized government leaders for mishandling the pandemic, and her critics could now point out that China had done much better than that of the United States. Her diary drew the special ire of Chinese nationalists, and she became the target of verbal abuse and even death threats. Fang Fang fought back on Weibo, and continues to this day to endure the ongoing consequences of her lockdown diaries, whose meaning retroactively transformed as the suffering of the rest of the world followed, and exceeded, that of Wuhan.

As online diary communities extended over time and geographical space, the affordances of platforms caused their character as friendly/unfriendly to change. Fang Fang posted her diaries both on Sina Weibo and on WeChat. ${ }^{2}$ On Weibo, postings are open to viewing and commenting, unless the account holder turns off the comment function. For most of the time she was posting diaries during the lockdown, Fang Fang did not close this function: her posts would often receive thousands of comments. Although most were positive and supportive, critics and trolls also used the space to ferociously attack her. Comments on WeChat are moderated and less likely to be offensive. It was also here that more closely-knit communities formed. After Fang Fang decided to stop writing in late March, her fans on WeChat started writing and posting their own diaries as "relay diaries" to carry on her cause. Reading Fang Fang's diary had become such a daily ritual that many found its absence unbearable. From March 27 to May 29, 60 people wrote 60 "relay diaries" to match the output Fang Fang's diary entries had maintained - an explicit example of the priority of the performance of community as the offer and product of the lockdown diary-writing.

\footnotetext{
${ }^{2}$ On WeChat, she did not post them personally. A writer friend in the U.S. who runs a WeChat public account published her diaries for her. See Er Xiang (2020)
} 


\section{Starting and (not) stopping: the paradox of performance}

These "relay diaries" raise a question of the span-a preoccupation of recent scholarship about a work of endurance art. Does it consist only in its live performance? In that case, how can it be repeated (conserved, preserved)? The fact that the life of Wuhan lockdown diaries did not 'end' when their authors stopped writing offers an interesting analogy for this question. The lockdown diaries' reification by repetition (a condition that is ongoing in the case of Fang Fang) resonates productively with some of the paradoxes scholars have associated with performance art.

Scholars in performance studies were initially fascinated with the ephemerality of performance art. Phelan, for example, considered "disappearance" as the most distinctive feature of performance art:

Performance's only life is in the present. Performance cannot be saved, recorded, documented, or otherwise participate in the circulation of representations of representations: once it does so, it becomes something other than performance. (Phelan 1993, p 146).

Others have highlighted the messy relationship between performance and disappearance, arguing that performance is not that which disappears, but is "an act of remaining, and a means of reappearance." (Schneider 2001, p 103). Schneider continues: "performance becomes itself through messy and eruptive reappearance, challenging, via the performative trace, any neat antinomy between appearance and disappearance, or presence and absence." On the basis of his study of Chris Burden's "Shoot," for example, Christopher Bedford (2012, p 86) expands this thinking in ways that could almost be describing Fang Fang's diaries and the various stages of their interactive reception:

Performance is a myth-making medium and as such essentially viral in nature. It extends indefinitely through history, its auratic charge often gaining traction and potency, just as the originary act recedes and recedes. It is the absence of the event, the absence of an object, which makes the work available for rewriting, and it is this quality that permits the work to travel through time and space, absorbing and assimilating the conditions of history. The moment of performance, then, is simply the beginning point, the source of the myth, one of its functions being the foundation of a viral chain, the ontology of which is predicated on perpetual revision, by historians and practitioners.
Shalson (2018, pp 32-33) argues that the performance of endurance art is bound to live beyond the live event, because it already engages with multiple temporalities:

Endurance works begin with decisions and plans made beforehand... and they continue afterward through the circulation of documents and accounts that generate powerful effects on viewers long after the performances are over. This is as true for performances that last a few minutes as it is for performances that last years. Hence, the time of endurance is multiple.

As an endurance art, lockdown diaries both are of, and seek to transcend, their moment. For many of the diarists who stopped writing when the lockdown ended, what they endured while writing their digital diaries lived on in other forms. But in what forms was a matter beyond their control, in the same way as the following through of their original plan of writing was hard to control, because, to repeat Shalson's (2020, p 12) point, the implementation of a plan happens in relation to other forces. All diarists practiced the art of endurance in their own ways to the extent that they persevered in writing and publishing diaries on social media despite the uncertainties about how and when the lockdown would end.

But Fang Fang's diary is the most dramatic example of this lack of control. As mentioned earlier, Fang Fang endured personal attacks while she was writing and posting her diaries: these attacks did not stop when she stopped writing but became even more vehement. The main reason for the heightened animosity toward her was the publication of the English translation of her diary in the United States. The English version of Fang Fang's diary continued (or reperformed) the life of her diary in a different time-space-outside China, after the pandemic had been contained in China. The consequences of the translation spawned complicated new plots. Even the English translator Michael Berry, a professor of Chinese literature at the University of CaliforniaLos Angeles, became the target of personal attacks from Chinese netizens on Sina Weibo. Professor Berry wrote in his "Translator's Afterword":

After receiving a series of texts from friends warning me about what was happening, I checked my Weibo account to find more than 600 messages and comments filled with hateful comments and threats against my family and me. These were all in response to news that an English edition of Fang Fang's Wuhan Diary was to be published and that I was the translator. (Berry 2020, p. 312).

Faced with growing hostility, Fang Fang carried on a fearless verbal battle with her attackers on Weibo. From April 29 to May 9, she posted a series of 9 new essays entitled 
"About" (关于), each the length of another diary entry. In them, she responded in painstaking patience and excruciating detail to all the accusations made against her. She had already given many of these explanations in her diaries or Weibo postings. But she decided to give her responses again and in greater detail by addressing all the issues one by one. For example, one accusation was that she did not personally experience or witness all the bad things she wrote about in her diaries; she had merely heard about them from other people while she never even left her house. In the second essay of the series, entitled "Hearsay," she countered: "In their view, there could be no truth without personally going to the site to investigate. Then let me ask: You didn't come to investigate me in my home. How did you know I never left my house?" (Fang Fang, "About," April 30, 2020). She reasoned:

The entire Wuhan is a live scene to me. I' $m$ in the middle of it. I'm one of the victims of the catastrophe. I can genuinely feel the fear and harm the epidemic brought to the people. Many of the things happened around me, within my sight. Sure, many of the small scenes I didn't visit nor could I. But I can still document them. For example, about Li Wenliang's death. I wasn't in Wuhan Central Hospital, but I could write about him. I never visited the fangcang temporary hospitals either, but I could also write about them.... I can use modern technologies to interview them and find out about their situation. In fact, many journalists did interviews in the same way. When they interviewed doctors about emergency care, they could not possibly be there on the scene. They could only listen to physicians' stories. Many journalists interviewed me through the internet. They never met me in person. You cannot say these interviews are fake or rumors....[...]...After all, I have lived in Wuhan for over 60 years. I went to elementary school, middle school, and college here. I worked as a factory worker, a journalist, a writer, and an editor. I know people from all walks of life in Wuhan. Many of them are my WeChat friends and in my contact list. Is it difficult for me to obtain information? ... My diaries were read by countless numbers of people. Many of them sent me all sorts of information. I have the names of all these informants. The information they gave me was almost always about their own family members or things that happened around them.

Fang Fang enumerated five sources of information for her diaries to refute the accusation that what she wrote about was hearsay. The point here is less about what Fang Fang wrote about, than how she did it. She explained in painstaking detail what it means to write about one's experiences while staying at home during the lockdown and why interviews and informants can provide legitimate information for her musings in her diary. It is almost as if she was explaining how to do investigative reporting or qualitative social science research during a pandemic. Doing this again and again amounts to a critical pedagogy of repetition in a school of endurance.

Fang Fang's repeated explanations, however, did not stop the attacks. One challenge for her was that forces beyond her control shaped reader responses. The attacks on her became especially venomous after Western politicians and media began using racist headlines, such as the "China virus" and "China is the real sick man of Asia" (Mead 2020) to scapegoat China as their countries struggled to control the virus. Sensationalist demands for China to pay reparations were made in the U.S. to deflect the administration's responsibility for failing to tackle the crisis (Shear et al 2020). These claims touched a deep historical nerve for Chinese who were reminded of humiliations imposed on China by Western powers through unequal treaties in the nineteenth century (Esherick 1987; Gries 2004; Wang 2012). All this led to a surge of patriotism among the Chinese public. Some diarists wrote that they felt so fortunate to be citizens in China (Sister Ma's Diary, April 22, 2020). It was under these circumstances that some readers who initially supported Fang Fang changed sides and began to call her a "traitor." If China was scapegoated for the policy failures in the U.S. in handling the pandemic, Fang Fang was scapegoated by Chinese nationalists for making China vulnerable to attacks from foreign countries. Fang Fang was forced to endure the rage of a nation, or at least part of it. Like a religious martyr, she was sacrificed by the community on the altar of the nation. Thus long after she has stopped her diary-writing, she must continue to endure the fact that her diaries, through iteration in a digital sphere, have a life of their own, in the same way that performance art is a prompt whose reactions will vary with different times, places and audiences. Stopping her lockdown diary was less an end than the beginning of her endurance, an outcome she could not have envisaged when she first started it.

Acknowledgements My first thanks go to the diarists cited in this article, especially Guo Jing (郭晶), Chu Ma (楚马), Tao Tao (桃桃), Wu Shangzhe (吴尚哲), and Xuan Yue (炫悦), who responded to queries about themselves and their diaries. Reading their lockdown diaries was an inspiration for my own stay-at-home life in Philadelphia. I am extremely grateful to guest-editors Clare Foster and Ruichen Zhang for their insightful comments and careful editing of this article. I would also like to thank Professor Liu Neng of Peking University and Doctor Ana Belen Martínez García of Universidad de Navarra for their 
valuable feedback. Finally, I'd like to thank students in my doctoral seminar on "The Performance Society" for analyzing the concept of endurance with me.

\section{References}

Bao H (2020) Three women and their Wuhan diaries: Women's writing in a quarantined Chinese city. Cha: An Asian Literary J. https://chajournal.blog/2020/10/17/wuhan-diaries/

Bedford C (2012) The viral ontology of performance. In: Jones A, Heathfield A (eds) Perform repeat record: live art in history. Intellect, Bristol, UK and Chicago, IL, pp 77-87

Berry M (2020) Translator's afterword, In: Fang F (eds) Wuhan diary: dispatches from a quarantined city, trans. Berry M. HarperCollins, New York, pp 305-313

Ben-Amos B, Dan B-A (eds) (2020) The diary: the epic of everyday life. 2nd revised ed. Bloomington, Indiana University Press, Indiana

boyd d (2010) Social network sites as networked publics: affordances, dynamics, and implications. In: Papachariss Z (ed) A networked self: identity, community, and culture on social network sites. Routledge, New York, pp 39-58

Buford L (2020) A journey through two decades of online diary community. In: Ben-Amos B, Ben-Amos Dn (eds) The diary: the epic of everyday life, 2nd revised edn. Indiana University Press, Bloomington, Indiana, pp 425-440

Chen Y, Mao Z, Qiu J (2018) Super-sticky WeChat and Chinese society. Emerald Publishing, UK

Cheung H, Feng H, Deng B (2020) Coronavirus: What attacks on Asians reveal about American identity. BBC News. https:// www.bbc.com/news/world-us-canada-52714804

China Internet Network Information Center (CNNIC) (2020) The 46th China statistical report on internet development. www. cnnic.net

Chun WHK (2008) The enduring ephemeral, or the future is a memory. Critical Inquiry, 35(1): 148-171. JSTOR. https://doi. org/10.1086/595632

Davidson H (2020) Chinese writer faces online backlash over Wuhan lockdown diary. The Guardian. https://www.theguardian.com/ world/2020/apr/10/chinese-writer-fang-fang-faces-online-backl ash-wuhan-lockdown-diary

Er Xiang (二湘) (2020) Editorial notes on Fang Fang diary: a beautiful bahttps://mp.weixin.qq.com/s/uEf2_9szRBYK0hzBoYow9wttle has been fought, a crown of justice is reserved for her (方方日 记编辑手记--美好的仗已经打完, 有公义的冠冕为她留存). Er Xiang's 11th Dimensional Space WeChat Public Account (二湘 的十一维空间). . Accessed 30 Nov 2020

Esherick JW (1987) The origins of the boxer uprising. University of California Press, Berkeley

Fang F (2020) Wuhan diary: dispatches from a quarantined city. HarperCollins, Translated into English by Michael Berry

Farrer J (2007) China's women sex bloggers and dialogic sexual politics on the Chinese internet. China aktuell 3:9-46

Gries PH (2004) China's New Nationalism: Pride, Politics, and Diplomacy (1st Edition). University of California Press.

Guo J (2020) Wuhan Lockdown Diaries (武汉封城日记) . Taiwan: Lianjing Chubanshe. Guo, S (2020) The evolution of the Chinese Internet: Creative visibility in the digital Public. Stanford University Press, Stanford
Han R (2018) Contesting cyberspace in china: online expression and authoritarian resilience. Columbia University Press, New York

Hockx M (2015) Internet literature in China. Columbia University Press, New York, pp 2015

$\mathrm{Hu} \mathrm{Y}$ (2008) the rising cacophony: personal expression and public discussion in the internet age (众声喧哗: 网络时代的个人表 达与公共讨论), Guangxi Teachers University Press, Beijing.

Lejeune P (2009a) Diaries on the internet: a year of reading. In: Jeremy D (ed) Lejeune P on diary. The biographical research center and the University of Hawaii Press, Popkin and Julie Rak. Honolulu, pp 299-316

Lejeune P (2009b) Spiritual journals in France from the sixteenth to the eighteenth centuries. In: Lejeune, P On Diary, edited by Jeremy D. Popkin and Julie Rak. The Biographical Research Center and the University of Hawaii Press, Honolulu, pp. 61-78

Łukianow M, Głowacka M, Helak M, Kościńska J, Mazzini M (2020) Poles in the face of forced isolation. A study of the polish society during the Covid-19 pandemic based on 'Pandemic Diaries' competition. Euro Soc 0(0):1-15. https://doi.org/10.1080/14616 696.2020 .1841264

Manley G (2020) Introducing the pandemic diaries. In: Manley G, Dougan BM, McGranahan C (eds) Pandemic Diaries, American Ethnologist website, https://americanethnologist.org/features/colle ctions/pandemic-diaries/introducing-the-pandemic-diaries.

Martínez García AB (2020) Women activists' strategies of online self-presentation. AI \& Soc. https://doi.org/10.1007/s00146-02001102-y

Marwick AE, boyd d (2011) I tweet honestly, I tweet passionately: Twitter users, context collapse, and the imagined audience. vol 13 issue 1: 114-133. https://doi.org/10.1177/1461444810365313

Mead WR (2020) China is the real sick man of Asia. Wall Street Journal. https://www.wsj.com/articles/china-is-the-real-sick-man-ofasia-11580773677

Mei CQ (2020) Policy style, consistency and the effectiveness of the policy mix in China's fight against COVID-19. Policy Soc 39(3):309-325. https://doi.org/10.1080/14494035.2020.1787627

Negro G (2017) The internet in china: from infrastructure to a nascent civil society. Palgrave Macmillan.

Nierenberg A (2020) The quarantine diaries. The New York Times. https://www.nytimes.com/2020/03/30/style/coronavirus-diariessocial-history.html

Phelan P (1993) Unmarked: the politics of performance, Routledge, London

Plummer K (2001) Documents of Life 2: an invitation to a critical humanism, 2nd edn. SAGE Publications, London

Qiu J (2009) Working-class network society: communication technology and the information Have-Less in Urban China. The MIT Press, Cambridge

Rak, J (2020) The diary among other forms of life writing. In: BenAmos B, Ben-Amos Dn (eds) The Diary: the epic of everyday life, 2nd revised ed. Bloomington, Indiana: Indiana University Press, pp. 57-72.

Rettberg JW (2020) Online diaries and blogs. In Ben-Amos, B and Ben-Amos, Dn (eds), The diary: the epic of everyday Life, 2nd revised ed. Bloomington, Indiana: Indiana University Press, pp 410-424.

Schneider R (2001) Performance remains. Performance Res 6(2):100-108

Shalson L (2018) Performing endurance: art and Politics since 1960. Cambridge University Press, Cambridge 
Shear MD, Weiland N, Lipton E, Haberman M, Sanger DE (2020). Inside Trump's failure: The rush to abandon leadership role on the virus. The New York Times. https://www.nytim es.com/2020/07/18/us/politics/trump-coronavirus-response-failu re-leadership.html

Wang W (2012) Never forget national humiliation: historical memory in Chinese politics and foreign relations. Columbia University Press, New York

Wilson J (2020) The rightwing groups behind wave of protests against Covid-19 restrictions. The Guardian. https://www.theguardia n.com/world/2020/apr/17/far-right-coronavirus-protests-restr ictions

Yang G (2009) The power of the internet in china: citizen activism online. Columbia University Press, New York
Yang G (2020) The digital radicals of Wuhan. CDCS Website. Retrieved December 9, 2020. https://cdcs.asc.upenn.edu/guobi n-yang-2/

Yang G, Wu S (2017) Remembering disappeared websites in China: Passion, community, and youth: New Media \& Society. https://doi. org/10.1177/1461444817731921

Publisher's Note Springer Nature remains neutral with regard to jurisdictional claims in published maps and institutional affiliations. 